\title{
WEBSITE DESA SEBAGAI WADAH POTENSI EKONOMI MANDIRI DESA DI ERA REVOLUSI INDUSTRI 4.0
}

\author{
Siti Aminah Anwar ${ }^{1}$, Muhammad Sulton' ${ }^{1}$, Ansharullah K. Zufri², Rohmat Arif ${ }^{3}$, \\ Muhammad Khoirudin'3 , Syaiful Fatur Rochman', Muhammad Darul Huda3 ${ }^{3}$ Nova Dwi \\ Cahyani1 $^{1}$, Dewi Sri Mulyani' ${ }^{1}$, Tri Nurmeisida ${ }^{3}$, Ratma Ana Tasya ${ }^{1}$ \\ ${ }^{1}$ Fakultas Ekonomi dan Bisnis, Universitas Islam Malang \\ ${ }^{2}$ Fakultas Hukum, Universitas Islam Malang \\ ${ }^{3}$ Fakultas Agama Islam, Universitas Islam Malang \\ ${ }^{4}$ Fakultas Keguruan dan Ilmu Pendidikan, Universitas Islam Malang \\ Korespondensi email: saminaha.mlg4@gmail.com
}

\begin{abstract}
ABSTRAK
Berbagai permasalahan terkait pembangunan dan keterbatasan infrastruktur, maka penggunaan dan pemanfaatan TIK tidak dijadikan prioritas utama oleh pemerintahan desa. Kesenjangan digital antara masyarakat perkotaan dan pedesaan seperti telepon seluler, komputer, maupun internet, serta ketersediaan SDM berbasis IT. Dengan demikian peserta KKN-PPM Tematik Unisma melalukan pengembangan website Desa dengan tujuan sebagai sarana akuntabilitas dan transparansi publik serta promosi potensi-potensi wisata desa. Metode penelitian yang digunakan adalah penelitian kualitatif dengan sampel yaitu potensi desa Amadanom. Hasil penelitian terkait pengembangan website dapat meningkatkan pendapatan warga desa amadanom dan segala potensi desa akan dipromosikan dalam website sehingga orang luar akan merasa tertarik mengunjungi tempat wisata di Desa Amadanom.
\end{abstract}

Kata Kunci: website; potensi desa.

\section{PENDAHULUAN}

Era Industri 4.0 merupakan bentuk perubahan didalam dunia teknologi berbasis internet. Berkembangnya revolusi industri 4.0 memberikan dampak positif dan negatif pada berbagai aspek kehidupan manusia (Prasetyo \& Sutopo, 2018). Perkembangan teknologi memiliki dampak yang cukup signifikan dalam mengubah tatanan kehidupan masyarakat. Dalam perkembangan ini terdapat hal positif dimana teknologi dapat mendukung kehidupan manusia, akan tetapi apabila teknologi tersebut bila disalahgunakan akan berdampak negatif kepada penggunanya (Adiansah et al., 2019). Adanya teknologi dan platform baru hasil dari perkembangan revolusi industri 4.0 akan semakin memungkin warga negara untuk terlibat dalam pemerintahan, menyuarakan pendapat mereka, mengkoordinasikan upaya mereka, dan bahkan menghindari pengawasan otoritras publik.

Menurut Haris (2019) karakteristik kunci dari revolusi industri 4.0 berupa kecepatan perubahan yang dialami oleh organisasi dan individu karena inovasi teknologi yang muncul menciptakan cara untuk mengembangkan, bertukar, dan mendistribusikan nilai di seluruh masyarakat merupakan titik temu antara revolusi industri 4.0 dengan dinamika politik berbasis digital. Dengan demikian adanya revolusi industri 4.0 sangat 
memungkinkan terjadinya perubahan sosial dan kebudayaan yang berlangsung secara cepat yang menyangkut dasar kehidupan masyarakat.

Menurut Destiningrum \& Adrian (2017) website merupakan keseluruhan halamanhalaman web yang terdapat dalam sebuah domain yang mengandung informasi baik berupa teks, gambar, maupun video. Revolusi Industri 4.0 secara fundamental mengakibatkan berubahnya cara manusia berpikir, hidup, dan berhubungan satu dengan yang lain. Era ini akan membantu berbagai aktivitas manusia dalam berbagai bidang, tidak hanya dalam bidang teknologi saja, namun juga bidang yang lain seperti ekonomi, sosial, dan politik (Prayitno \& Safitri, 2015). Di sektor ekonomi telah terlihat bagaimana sektor jasa transportasi dari kehadiran taksi dan ojek daring. Hal yang sama juga terjadi di bidang sosial dan politik. Interaksi sosial pun menjadi tanpa batas (unlimited), karena kemudahan akses internet dan teknologi. Hal yang sama juga terjadi dalam bidang politik. Melalui kemudahan akses digital, perilaku masyarakat pun bergeser. Aksi politik kini dapat dihimpun melalui gerakan-gerakan berbasis media sosial dengan mengusung ideologi politik tertentu (Saragih, 2018).

Namun di balik kemudahan yang ditawarkan, Revolusi Industri 4.0 menyimpan berbagai dampak negatif, diantaranya ancaman pengangguran akibat otomatisasi, kerusakan alam akibat eksploitasi industri, serta maraknya hoax akibat mudahnya penyebaran informasi. Oleh karena itu, kunci dalam menghadapi Revolusi Industri 4.0 adalah selain menyiapkan kemajuan teknologi, di sisi lain perlu dilakukan pengembangan sumber daya manusia dari sisi humaniora agar dampak negatif dari perkembangan teknologi dapat ditekan (Kurniawati et al., 2019).

Salah satu faktor yang menyebabkan kesenjangan digital antara wilayah perkotaan dan perdesaan adalah belum meratanya infrastruktur dan ketersediaan sumber daya manusia (SDM) teknologi informasi dan komunikasi (TIK), yang berpengaruh terhadap pemanfaatan TIK di tingkat desa. Akibat menghadapi berbagai permasalahan terkait pembangunan dan keterbatasan infrastruktur, maka penggunaan dan pemanfaatan TIK tidak dijadikan prioritas utama oleh pemerintahan desa. Namun di balik keterbatasan tersebut, muncul desa-desa yang mampu menggunakan dan memanfaatkan TIK guna mendukung kegiatan-kegiatan yang dilakukan di desa, sehingga mampu meningkatkan pembangunan tersebut. Kesenjangan digital antara masyarakat perkotaan dan pedesaan merupakan salah satu masalah yang dihadapi negara berkembang. Kesenjangan tersebut dapat diakibatkan oleh berbagai faktor diantaranya kesenjangan infrastruktur antara kota dan desa, maupun tingkat kebutuhan masyarakat akan fasilitas dan perangkat TIK seperti telepon seluler, komputer, maupun internet, serta ketersediaan SDM berbasis IT, yang berpengaruh terhadap pemanfaatan TIK ditingkat desa (Arifin et al., 2020).

Dari permasalahan tersebut, maka dapat dilakukan pembuatan website di Desa Amadanom dengan tujuan untuk memudahkan masyarakat dalam mendapatkan informasi mengenai Desa Amadanom meliputi profil desa, potensi ekonomi desa, dan produk unggulan Desa Amadanom. Selain itu, dari pembuatan website desa, kami juga dapat memperkenalkan mengenai Universitas Islam Malang. Penelitian ini dilakukan agar dapat meningkatkan kesadaran masyarakat dalam meningkatkan potensi-potensi yang ada di Desa. Sehingga dapat memajukan kesejahteraan masyarakat baik dari segi ekonomi, politik sosial maupun budaya dan Mahasiswa dapat memperoleh pengetahuan atau wawasan dalam meningkatkan potensi ekonomi mandiri yang ada di Desa melalui website.

Selain itu dengan adanya website Desa Amadanom diharapkan bisa digunakan sebagai sarana akuntabilitas dan transparansi publik serta promosi potensi-potensi wisata desa. Melalui website desa diharapkan seluruh kegiatan perencanaan ataupun hasil dari 
pengelolaan pembangunan desa dapat diakses dan diketahui oleh masyarakat desa. Diharapkan juga website Desa Amadanom nantinya bisa menjadi media promosi bagi produk-produk di Desa Amadanom sehingga bisa lebih dikenal masyarakat luas.

Tujuan pembuatan website desa tidak lain untuk mempublikasikan keberadaan desa ke dunia luar, sehingga mudah untuk diketahui banyak orang, menginformasikan profil dan potensi desa, mempermudah masyarakat luas untuk memperoleh informasi mengenai desa sebagai bentuk keterbukaan informasi publik, menjadi wadah dokumentasi segala kegiatan yang dilakukan masyarakat desa dengan mengunggah foto dan video kegiatan, menjadikan media promosi produk desa, dan menjadikan media pengumuman bagi warga desa, sehingga pengumuman yang berkaitan dengan desa dapat dilihat baik oleh warga desa maupun luar desa.

Banyak manfaat yang bisa didapat dengan adanya website desa yaitu meningkatkan citra desa, meningkatkan kualitas SDM desa, meningkatkan keunggulan desa, dan penyampaian dan penyebarluasan informasi yang ada di desa. Hal ini sejalan dengan pendapat Ahyuna et al. (2013) bahwa fungsi website merupakan sebagai Media Promosi, Media Pemasaran, Media Informasi, Media Pendidikan, dan Media Komunikasi. Dengan demikian website desa merupakan salah satu media untuk mempromosikan potensipotensi yang ada di Desa. Maka dari itu perlu dukungan semua pihak baik dari pemerintah desa maupun masyarakat desa untuk bisa mempromosikan potensi desa ke hadapan dunia luar.

\section{METODE}

Metode yang digunakan adalah dengan metode pendekatan yang diharapkan bisa mendeskripsikan potensi yang bisa dikembangkan. Lokasi penelitian dilaksanakan di kantor desa Amadanom kecamatan Dampit kabupaten Malang Provinsi Jawa Timur. Dengan waktu yang digunakan untuk penelitian mulai 1 Februari 2020 sampai dengan 1 Maret 2020. Subyek pada penelitian ini adalah perangkat desa di kantor Desa Amadanom dengan obyeknya berupa website desa.

Saat ini Pemerintahan Desa Amadanom sudah memiliki website desa yaitu desaamadanom.malangkab.go.id yang berisi berbagai konten informasi maupun berita mengenai Desa Amadanom. Website desa Amadanom saat ini sudah berisi berbagai konten seperti sejarah desa, visi misi desa, profil desa, berita desa dan artikel mengenai produk unggulan Desa Amadanom. Kami disini untuk pengembangan Website Desa Amandanom menambah beberapa konten untuk pengenalan yang lebih luas keunggulan-keunggulan yang dimiliki desa Amandanom menuju desa mandiri yang memiliki potensi ekonomi

\section{HASIL DAN PEMBAHASAN}

Desa amadanom adalah sebuah desa yang terletak di kecamatan dampit kabupaten malang provinsi jawa timur. Dimana luas desa dan kelurahan amadanom mencapai 611. 430.000 ha. Kebanyakan penduduk bermata pencahariaan berkebun dengan tanaman komoditi kopi. Salah satu ciri khasnya adalah Kopi Hitam Robusta Organik dan Kopi Hijau Robusta Organik. Desa Amadanom memiliki beberapa potensi yang bisa dikembangkan terutama pengembangan yang berhubungan dengan kopi karena Desa Amadanom terkenal dengan kopi hitam Robusta yang memiliki rasa yang khas. Namun ada juga tanaman lain seperti singkong, kakao dan pohon Sengon. Jumlah penduduk sekitar 6734 orang.

Di Desa Amadanom Kecamatan Dampit Kabupaten Malang, terdapat destinasi wisata di bidang agrowisata yang dikonsep dengan model ekowisata. Letaknya di pinggir jalur utama Tur Amtirdam (Turen-Ampelgading-Tirtoyudo Dampit). Ekowisata ini diberi nama Ekowisata Kebun Kopi Amadanom yang sudah siap menyuguhkan potensinya dalam 
hal pertanian dan pengolahan kopi bagi wisatawan. Ekowisata ini suatu perwujudan dari kelompok Tani Harapan yang menawarkan konsep menanam tanaman kopi dari hulu sampai hilir dan sebagai tempat edukasi kepada masyarakat yang akan melakukan kegiatan berwisata sambil belajar.

Selain itu, terdapat bukit Van D'Kock yang merupakan tempat wisata baru dan masker kopi yang merupakan hasil inovasi dari mahasiswa KKN-PPM Tematik Unisma yang ingin kami promosikan melalui website desa. Potensi-potensi yang dimiliki oleh Desa Amadanom ini harus dikelola dan dipromosikan dengan baik sehingga akan menjadi salah satu pemasukan pendapatan bagi desa. Dalam rangka pengenalan potensi yang dimiliki Desa Amadanom maka diperlukan salah satu media informasi yang baik salah satunya melalui pengelolaan website. Website Desa merupakan salah satu gagasan dari pemerintah desa yang muncul berdasarkan UU NO 6 tahun 2014 tentang Desa Pasal 26 Ayat 1 yang berisi "Kepala Desa bertugas menyelenggarakan Pemerintah Desa, melaksanakan Pembangunan Desa, pembinaan kemasyarakatan desa, dan pemberdayaan masyarakat Desa" dan Ayat 2 yang berbunyi "Dalam melaksanakan tugas sebagaimana dimaksud pada ayat 1, Kepala desa berwenang membina dan meningkatkan perekonomian desa serta mengintegrasikannya agar mencapai perekonomian skala produktif untuk sebesarbesarnya kemakmuran masyarakat desa". Website desa dikelola oleh pemerintah desa yang bertujuan untuk meningkatkan pendapatan warga desa khususnya yang berwirausaha. Warga masyarakat dapat memanfaatkan website desa sebagai salah satu sarana penyebaran usaha maupun hasil pertanian dan peternakan agar sekiranya dapat berdampak positif bagi para pelaku ekonomi di Desa Amadanom.

Di desa amadanom adalah tipe desa yang berpotensi dalam bidang pariwisata dan pertanian, dimana dibidang pariwisata tersebut terdapat beberapa tempat wisata yang namanya gunung van de kock dan juga eco wisata kebun kopi, dan di bidang pertanian terdapat banyak kekayaan alam yang dapat dikelola, contohnya seperti kelapa, duren, dan kopi. Tapi yang paling mencolok dan berpotensi besar untuk dikelola dan dipasarkan hingga sekarang adalah tumbuhan kopi, dengan mayoritas tanaman vegetatif coffea (tanaman kopi) maka mengingat pendapatan ekonomi dari warga yang berprofesi sebagai petani di desa amadanom sendiri adalah dari pengolahan dan pemasaran kopi itu sendiri.

Akan tetapi sangat disayangkan dari desa amadanom adalah kemajuan teknologi yang kurang berkembang sehingga potensi-potensi yang ada di desa tidak banyak diketahui oleh dunia luar, maka dari itu kami dari KKN-PPM Tematik unisma mengadakan sosialisasi media sosial di era 4.0 dan membuat program tentang website desa, dengan tujuan untuk lebih memperkenalkan atau mempromosikan potensi yang ada di desa amadanom baik dari bidang pariwisata maupun perkebunan, disamping itu kami melihat desa amadanom sangat cocok untuk diadakan program kerja yang berhubungan dengan alam perkebunan dan pariwisata, oleh karena itu Kami mengangkat beberapa informasi yang ada di desa amadanom yaitu yang berhubungan tentang potensi yang ada di desa, saat ini desa amadanom berada dalam situasi yang dimana masyarakat amadanom belum memiliki skill untuk mengembangkan potensi-potensi yang dimiliki Desa Amadanom, maka dalam hal ini merupakan sebuah peluang bagi kita untuk mengembangkan dan memperkenalkan kekayaan alam dan kearifan lokal dari desa amadanom. 


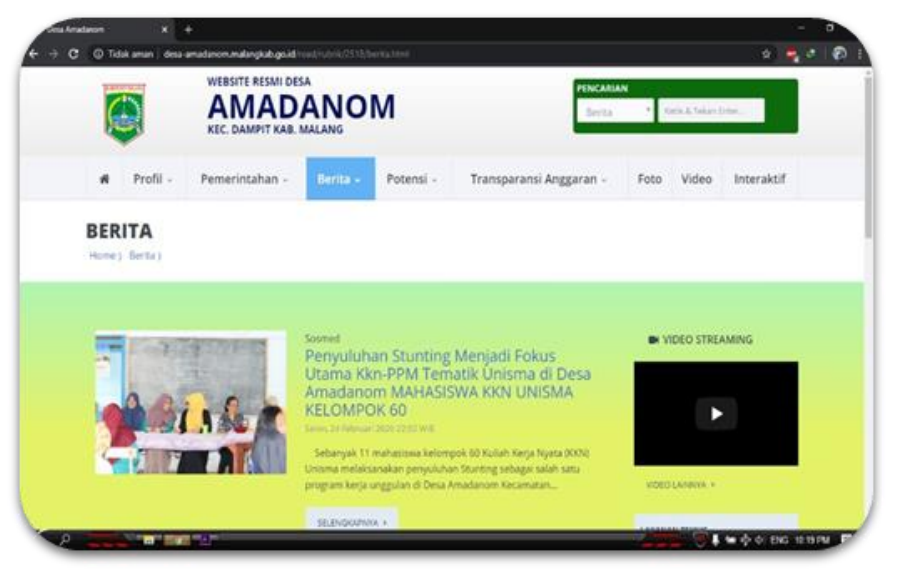

Gambar 1. Web Desa Amandanom

Untuk memperkenalkan potensi tersebut program kami adalah untuk mengembangkan media berupa website yang berguna untuk mempermudah akses dari desa amadanom guna memperkenalkan potensinya kepada masyarakat di luar desa amadanom, karena sekarang kita berada di era industri 4.0 yang rata-rata menggunakan media internet untuk mengakses beberapa informasi maupun hal lain. Desa amadanom yang mayoritas potensi ekonominya belum dikenal oleh masyarakat di luar desa amadanom, sehingga potensi ekonomi desa amadanom seperti pariwasata bukit van de kock dan eco wisata kopi yang sampai sekarang masih sepi pengunjung, serta pengembangan kopi yang berada di desa amadanom belum terlalu terekspose di luar Desa Amadanom.

Disamping itu di desa amadanom ada fasilitas desa berupa BUMDES (Badan Usaha Milik Desa) dimana pada awalnya BUMDES koperasi hanya menyediakan berbagai macam ATK yang dimana konsumennya adalah warga sekitar BUMDES saja. Sehingga Kami berinisiatif untuk mengembangkan BUMDES tersebut dengan mengembangkan fasilitas yang berupa Token listrik, pulsa dan berbagai macam pembelian online lainnya. Dengan fasilitas yang bertambah tersebut, Kami mempromosikan fasilitas BUMDES baru tersebut ke website untuk mengenalkannya ke warga sekitar desa Amadanom maupun desa luar guna menambah pemasukan ekonomi warga dan juga mempermudah warga desa amadanom dan sekitarnya untuk melakukan transaksi jual beli online yang berupa token listrik, pulsa dan lain-lain yang disediakan oleh BUMDES, maka dari itu kami mengembangkan website yang bisa di akses khalayak umum tersebut dan untuk alamat websitenya adalah www.desa-amadanom.malangkab.go.id.

Pengaruh website terhadap perkembangan masyarakat desa amadanom sendiri sudah bisa kita lihat dari pengolahan BUMDES, terkait dengan pembelian token listrik dan lain-lain melalui sarana online, dimana kita sebagai mahasiswa KKN TEMATIK UNISMA menyediakan fasilitas untuk BUMDES berupa pembelian online terkait dengan penyediaan kebutuhan yang sudah tersedia di BUMDES, selain itu kita juga memasukan data terkait pariwisata yang ada di desa, sehingga warga desa bisa terus mengembangkan website desa terkait dengan perkembangan informasi pariwisata di desa amadanom, dan fungsi website juga bisa digunakan oleh masyarakat desa untuk mengekspor berbagai jenis kopi yang ada di desa amadanom.

Terkait dengan wadah pengembangan perekonomian untuk warga desa sendiri sudah bisa kita lihat di bahasan sebelumnya, bahwasannya fungsi website desa sendiri sudah ada perkembangannya, dimana informasi tentang pariwisata,BUMDES, dan juga kopi yang ada di desa amadanom sendiri bisa mendatangkan pengunjung kalo mereka menggunakan website desa dengan baik dan benar, dimana ketika mereka kreatif dalam 
mengelola website maka kemungkinan besar orang yang membaca website juga akan ada rasa tertarik untuk mengunjungi sumber daya yang ada di desa amadanom, dari pengunjung yang akan datang itulah warga bisa memanfaatkan sumberdaya yang dikunjungi oleh pelancong atau masyarakat diluar maupun didalam desa menjadi sumber perekonomian warga desa amadanom sendiri.

\section{KESIMPULAN}

Dengan adanya website desa masyarakat mampu mengenalkan/mempromosikan potensi Desa Amadanom melalui media online, sehingga lebih mudah di akses oleh masyarakat di Era Industri 4.0 ini, dan website Desa Amadanom memberikan keuntungan tersendiri bagi masyarakat, karena dapat menambah konsumen atau pengunjung wisata yang ada di Desa Amadanom.

Setelah kegiatan KKN-PPM Tematik unisma diharapkan kepada perangkat desa dan masyarakat amadanom untuk tetap mengembangkan website desa tersebut dengan mengisi segala potensi yang ada di Desa Amadanom.

\section{DAFTAR RUJUKAN}

Adiansah, W., Setiawan, E., Kodaruddin, W. N., \& Wibowo, H. (2019). Person in Environment Remaja Pada Era Revolusi Industri 4.0. Focus : Jurnal Pekerjaan Sosial, 2(1), 47-60. https://doi.org/10.24198/focus.v2i1.23118

Ahyuna, Hamzah, M. D., \& HM, M. N. (2013). Pemanfaatan Internet Sebagai Media Promosi Pemasaran Produk Lokal Oleh Kalangan Usaha Di Kota Makassar. Jurnal Komunikasi KAREBA, 2(1), 30-40. https://doi.org/DOI: http://dx.doi.org/10.31947/kjik.v2i1.346

Arifin, Z., Budi Wahono, B., Prihatmoko, D., \& Riyoko, S. (2020). Inovasi Peningkatan Hasil Tangkapan Ikan Produk Unggulan Daerah oleh Nelayan Purse Seine Menggunakan Teknologi GPS. Jurnal Inovasi Hasil Pengabdian Masyarakat (JIPEMAS), 3(1), 54-62. https://doi.org/10.33474/jipemas.v3i1.4779

Destiningrum, M., \& Adrian, Q. J. (2017). Sistem Informasi Penjadwalan Dokter Berbassis Web Dengan Menggunakan Framework Codeigniter (Studi Kasus: Rumah Sakit Yukum Medical Centre). Jurnal Teknoinfo, 11(2), 30-37. https://doi.org/10.33365/jti.v11i2.24

Haris, M. (2019). Manajemen Lembaga Pendidikan Islam Dalam Menghadapi Revolusi Industri 4.0. Mudir: Jurnal Manajemen Pendidikan, 1(1), 45-57. https://ejournal.insud.ac.id/index.php/MPI/article/view/26

Kurniawati, E., Santoso, A., \& Widowati, S. Y. (2019). Pelatihan Pemasaran Online Bagi Kelompok Usaha Bersama (KUB) "SRIKANDI". Jurnal Inovasi Hasil Pengabdian Masyarakat (JIPEMAS), 2(2), 132-138. https://doi.org/10.33474/jipemas.v2i2.2722

Prasetyo, H., \& Sutopo, W. (2018). Industri 4.0: Telaah Klasifikasi Aspek Dan Arah Perkembangan Riset. J@ti Undip: Jurnal Teknik Industri, 13(1), 17-26. https://doi.org/10.14710/jati.13.1.17-26

Prayitno, A., \& Safitri, Y. (2015). Pemanfaatan Sistem Informasi Perpustakaan Digital Berbasis Website Untuk Para Penulis. IJSE - Indonesian Journal on Software Engineering Pemanfaatan, 1(1), 1-10. https://doi.org/10.4028/www.scientific.net/AMR.756-759.138

Saragih, M. Y. (2018). Jurnalisme: Harapan dan Tantangan di Era Revolusi Industri 4.0 Dalam Mendidik Masyarakat. Attaqwa: Jurnal Ilmu Pendidikan Islam, 14(1), 25-38. https://jurnal.staidagresik.ac.id/index.php/attaqwa/article/view/29 